\title{
Baseline for monitoring and habitat use of medium to large non- volant mammals in Gran Sabana, Venezuela
}

\author{
Izabela Stachowicz ${ }^{1,2 *}$, José Rafael Ferrer Paris ${ }^{3,4}$, Marcial Quiroga-Carmona ${ }^{5}$, Lisandro Moran ${ }^{3}$, and CeCilia Lozano 3,6 \\ ${ }^{1}$ Centro de Ecología, Instituto Venezolano de Investigaciones Científicas. Carretera Panamericana km11, 1020-A,. Caracas, \\ Venezuela. Email: stachowicz.izabela@gmail.com (IS). \\ 2 Department of Biodiversity Studies and Bioeducation, Faculty of Biology and Environmental Protection, University of Łódź, \\ Banacha 1/3, 90-237. Łódź, Poland. \\ ${ }^{3}$ Centro de Estudios Botánicos y Agroforestales, Instituto Venezolano de Investigaciones Científicas. Sede IVIC-Zulia, 1020-A. \\ Maracaibo, Venezuela. Email: leucemio17@gmail.com (LM), lozanoceci@gmail.com (CL). \\ ${ }^{4}$ Centre for Ecosystem Science, School of Biological, Earth and Environmental Sciences, University of New South Wales, 2052. Sydney, \\ Australia. Email: j.ferrer@unsw.edu.au (JRFP). \\ ${ }^{5}$ Facultad de Ciencias, Universidad Austral de Chile, Campus Isla Teja. Avda. Rector Eduardo Morales s/n, 5090000. Valdivia, Chile. \\ Email:marcialquiroga@gmail.com (MQ-C). \\ ${ }^{6}$ Instituto de Biociências, Universidade Federal de Mato Grosso, Av. Fernando Corrêa da Costa, 2367 Bairro Boa Esperança, $78060-$ \\ 900. Cuiabá, Brasil. \\ *Corresponding author
}

The Gran Sabana is a region of great biogeographical and conservation value that has been recently threatened due to increasing overexploitation of natural resources and illegal mining. Systematic survey methods are required in order to study species responses to landscape transformation. The main objectives of this study were: 1) to test the relationship between habitat types and mammal species presence in the Gran Sabana and Canaima National Park (NP), and 2) establish baseline methodology that can set guidelines for future, considering sampling limitations, conservation opportunities and increasing threats to biodiversity in this region. We implemented a stratified sampling design using camera traps for monitoring medium and large mammals in two previously under-sampled regions in the Gran Sabana, south-east Venezuela. We analysed time-series of remotely sensed vegetation indices to classify habitat types and summarized relative abundance of mammals, naïve occupancy, and habitat fidelity for each type. With a sampling effort of 5,523 camera*days, 29 species of mammals were recorded, including endangered Priodontes maximus, and vulnerable: Speothos venaticus, Tapirus terrestris, and Panthera onca. Cuniculus paca and Dasyprocta leporina were the most frequently registered, while Hydrochoeris hydrochaeris, Leopardus wiedii, and Leopardus tigrinus had few records. Most of the species were associated with forest (13), fewer with transitional shrub (7) and savanna (5) habitats, but only some of these were statistically significant. Cerdocyon thous show significant association with savanna $(P<0.01)$, whereas Leopardus pardalis $(P<0.05)$ and Cuniculus paca $(P<0.05)$ with shrub-intermediate habitat. As many as seven species: Dasypus kappleri, Dasyprocta leporine, Mazama americana, M. gouazoubira, Nasua nasua, Priodontes maximus, and Tapirus terrestris have statistically significant association to forest habitat $(P<0.05)$. We present the first record Myoprocta pratti for Canaima NP. We found higher species richness of large- and medium-sized mammals comparable to lowland Guianas and Amazon sites. Four species remained undetected, probably due to low abundance or detectability, but Sylvilagus brasiliensis seems to be truly absent from the Gran Sabana. Uncontrolled development of Orinoco Mining Arc on the border of Canaima NP and the Gran Sabana raised new ecological and social concerns.

La Gran Sabana es una región de gran importancia biogeográfica y valor para la conservación que se encuentra crecientemente amenazada debido a la sobre-explotación de los recursos naturales y la minería ilegal. Para estudiar las respuestas de las especies a la transformación del paisaje es necesario un programa de seguimiento sistemático. Los objetivos principales de este estudio fueron: 1) evaluar la relación entre los tipos de hábitat y la presencia de especies de mamíferos en la Gran Sabana y el Parque Nacional (PN) Canaima, y 2) establecer un método de referencia para el monitoreo a largo plazo considerando las limitaciones de muestreo, oportunidades para la conservación y amenazas crecientes para la biodiversidad en esta región. Se implementó un diseño de muestreo estratificado basado en cámaras trampas para monitorear mamíferos medianos y grandes en dos regiones previamente sub-muestreadas en la Gran Sabana, sureste de Venezuela. Analizamos series de tiempo temporales de índices de vegetación con sensores remotos para clasificar los tipos de hábitat y resumimos la abundancia relativa de mamíferos, la ocupación naïve y la fidelidad para cada tipo de hábitat. Con un esfuerzo de muestreo de 5,523 cámara*días, se registraron 29 especies de mamíferos, incluidas cuatro especies amenazadas: Priodontes maximus, categoría En Peligro, el Speothos venaticus, Tapirus terrestris y Panthera onca, estos tres en categoría Vulnerables. Cuniculus paca y Dasyprocta leporina tuvieron mayor cantidad de registros, mientras que Hydrochoerus hydrochaeris, Leopardus wiedii y Leopardus tigrinus tuvieron pocos registros. La mayoría de las especies están asociadas con el bosque (13) y en menor medida con hábitats de arbustos (de transición; 7) y de sabana (5), pero sólo algunas tuvieron asociaciones estadísticamente significativas. Cerdocyon thous muestra una asociación significativa con la sabana $(P<0.01)$, mientras que el Leopardus pardalis $(P$ $<0.05)$ y Cuniculus paca $(P<0.05)$ con el hábitat intermedio. Hasta siete especies: Dasypus kappleri, Dasyprocta leporina, Mazama americana, Mazama gouazoubira, Nasua nasua, Priodontes maximus y Tapirus terrestris tienen una asociación estadísticamente significativa con el hábitat forestal $(P<0.05)$. Se presenta el primer registro de Myoprocta pratti para PN Canaima. Se registró una mayor riqueza de especies de mamíferos grandes y medianos en comparación con las tierras bajas de las Guayanas y Amazonia. Cuatro especies permanecieron sin ser detectadas, probablemente debido a la baja abundancia o detectabilidad, pero Sylvilagus brasiliensis parece estar ausente de la Gran Sabana. El desarrollo incontrolado del Arco Minero del Orinoco en la frontera del PN Canaima y la Gran Sabana genera nuevas preocupaciones ecológicas y sociales.

Keywords: camera trap; Canaima National Park; Guiana Shield; Orinoco Mining Arc; Priodontes maximus; Speothos venaticus: Venezuelan Guayana. 


\section{Introduction}

The Gran Sabana (GS) has been considered an international conservation priority due to its high biodiversity and endemism of fauna and flora (Huber and Foster 2003). Historically low levels of human population, with low pressure and exploitation contrast with the rapid development in the last two decades. The Canaima National Park (NP), covering significant part of the GS, is among the UNESCO Natural World Heritage Sites with the highest deforestation rate in the South America (Allan et al. 2016) and illegal mining activities have increased drastically, especially since the declaration of the Orinoco Mining Arc (OMA, Zona de Desarrollo Estratégico Nacional Arco Minero del Orinoco) in 2016. This situation has aggravated threats to medium and large sized mammals that play key roles in sustaining native vegetation, and are sensitive to the effects of land cover change. Moreover, the profound economic crisis in Venezuela also makes bush meat an important source of protein (Rodríguez 2000) especially for indigenous Pemón communities in this region.

Mammals represent a rich but understudied animal group in the Gran Sabana. The earliest known and documented records of mammals collected in Venezuelan part of Guiana Shield were made by Alexander von Humboldt at the beginning of the 19th century. Subsequently, during the 1960's the Smithsonian Venezuelan Project, Handley (1978) carried out expeditions that documented presence of mammals particularly in three location and their surroundings in GS: Kavanayen, El Pauji, and Roraima Mountain. Recently, other inventories of mammals have been conducted in this region but have been focused on bats and small rodents (Ochoa et al. 1993; Ochoa 2001; Lim et al. 2005; Lew et al. 2009), as opposed to medium-sized species of mammals. The 151 species documented in the Canaima NP represent $40 \%$ of mammal species of Venezuela and $61 \%$ of the Guayana region (Lew et al. 2009). This mammal assemblage is dominated by bats ( 74 species) and rodents ( 29 species), but has an important component of carnivores represented by 16 species (Lew et al. 2009). Most studies have focused in basic inventory (Handley 1978; Ochoa et al. 1993; Ochoa 2001; Lew et al. 2009), but preliminary ecological categorization suggest that most species can be classified into two main groups defined by habitat (Ochoa et al. 1993; Huber et al. 2001). The first group is represented by frugivorous, omnivorous, and large predatory species mostly associated with forest and shrubland environments, and includes Panthera onca, Nasua nasua, and edentates such as Tamandua tetradactyla and Priodontes maximus. The second group consists of herbivores, omnivores, and small vertebrate predators inhabiting herbaceous high-tepui and savanna ecosystem, and includes Cerdocyon thous, Puma yagouaroundi and edentates such as Myrmecophaga tridactyla and Dasypus novemcinctus.

Long term monitoring of medium and large size mammals allows a deeper understanding of the ecological consequences of changes in land cover change, and the hidden threat of over-exploitation (Hoppe-Dominik et al. 2001). The use of camera trap for ecological studies has become a valuable tool for the observation and recording of large and medium mammals. It is especially a costeffective method for studying the presence and behavior of rare and elusive species (Lyra-Jorge et al. 2008; Cove et al. 2013; Morán et al. 2018). In this study, we present the results of a first survey of medium and large size mammals in previously under-sampled regions of GS, located on the north and north-east of the Canaima NP (Figure 1). The main objectives of this study were: 1) to test the relationship between broad habitat types and mammal species in GS and Canaima NP, and 2) establish baseline methodology that can set guidelines for future, long-term monitoring. First, we characterized habitat types according to time series of remotely sensed data and used information about presence and frequency of common and elusive medium and large mammals from camera-traps, tracks records and interviews, in order to assess the strength of perceived ecological categorizations. Then, we summarize the base line results considering the sampling efficiency and drawbacks of camera trapping in open habitats like savanna, the observed discrepancies between expected and detected species lists, conservation opportunities and increasing threats to the fauna and ecosystems found in the Canaima NP and surroundings.

\section{Materials and Methods}

Study area. GS holds anomalous vegetation - treeless savannas and forest-savanna mosaics and is characterized by a complex relief that varies in elevation from $500 \mathrm{~m}$ to $1,450 \mathrm{~m}$ and covers ca. 18,000 $\mathrm{km}^{2}$ of extension (Huber et al. 2001). The study area covers $1,442 \mathrm{~km}^{2}$ with elevations ranging from 700 to 1,400 masl of the sector 5 , on the north of GS. We conducted our studies in two sampling areas. The first area was sampled between September 2015 - April 2016, situated close to the Venezuela-Guyana international border and was delimitated by three indigenous Pemón communities: Kawi $\left(5.451^{\circ} \mathrm{N},-61.243^{\circ} \mathrm{W}, 1,100\right.$ masl), UroyUaray $\left(5.442^{\circ} \mathrm{N},-61.232^{\circ} \mathrm{W}, 1,093 \mathrm{masl}\right)$, and Wuarapta $\left(5.512^{\circ} \mathrm{N},-61.157^{\circ} \mathrm{W}, 896\right.$ masl; Figure 1$)$. The second area was sampled between May - July 2018 located on the west part of sector 5 in the vicinity of communities Kavanayen $\left(5.594^{\circ} \mathrm{N},-61.761^{\circ} \mathrm{W}, 1,222\right.$ masl), Liworibo (5.559 $\mathrm{N},-61.490^{\circ} \mathrm{W}, 1,255 \mathrm{masl}$ ) and research station Parupa $\left(5.5677^{\circ} \mathrm{N},-61.544^{\circ} \mathrm{W}, 1,267\right.$ masl). Vegetation in this sector of Gran Sabana is characterized by shrubs dominated by Clusia spp. and Gongylolepis spp., broadleaf grasslands and savannas of Axonopus spp. interrupted by gallery forest patches and continuous evergreen montane forest near to the llú - Tramén-tepui massif and Ptari tepui (Huber et al. 2001). The climate is submesothermic ombrophilous characterized by annual average temperatures between 18 and $24{ }^{\circ} \mathrm{C}$ and 2,000 to $3,000 \mathrm{~mm}$ of total annual rainfall with a weak dry season ( $<60 \mathrm{~mm} / \mathrm{month}$ ) from December to March (Rull et al. 2013). 


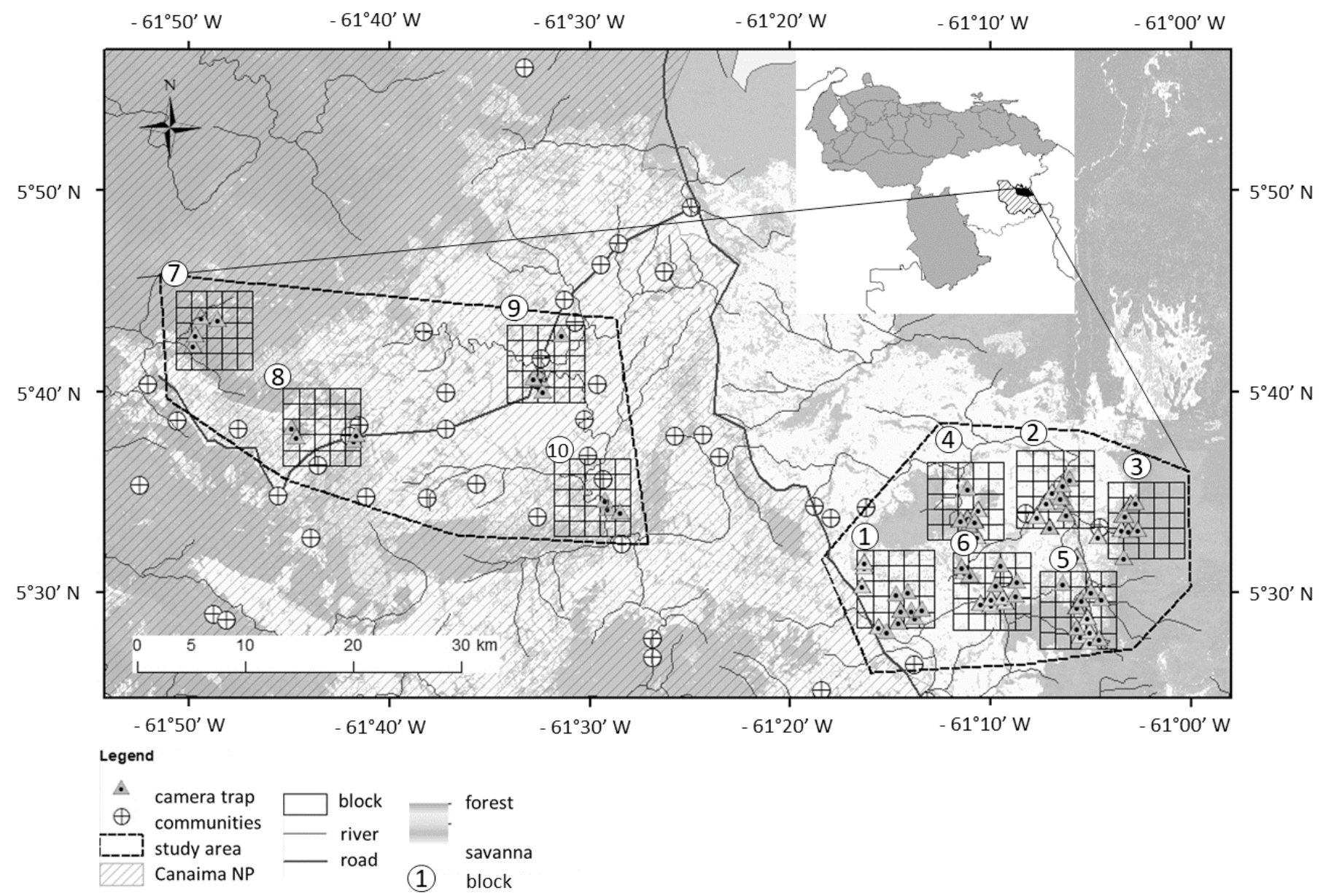

Figure 1. Location of study area in the Gran Sabana, outside (blocks 1 to 6) and inside (blocks 7 to 10) Canaima National Park, Venezuela.

Sampling procedure. In order to cover a large area and a diversity of habitats we selected ten blocks (each covering an area of $50 \mathrm{~km}^{2}$ ) representing different landscape configurations. We used series of Landsat satellite images from 2000 to 2016 to estimate forest cover (Sexton et al. 2013). Each block was divided in 25 sampling units of $2 \mathrm{~km} 2$ that were tentatively classified in four levels based on forest cover: continuous forest $(F)$, fragmented with predominance of forest ( $f$ ), fragmented with predominance of savanna (s) and savanna (S). ArcGIS 10.1 (ESRI 2012) and R version 1.0.153 (ㅁ Core Team 2013) were used for spatial analyses.

Because sampling effort was limited by the number of available cameras (30), we used one camera per sampling unit. Each sampling period lasted 60 days. On the first period we sampled five sampling units (five cameras) with different vegetation characteristics in each of blocks. For the remaining three periods (four in total) we moved the position of the cameras between different sampling units within each block. The rotation of cameras in the blocks assured a balanced representation of different landscape configurations and local conditions. Minimal distance between cameras was $1 \mathrm{~km}$. In continuous savanna (S) and habitat with predominance of savanna (s) we located 39 cameras, in continuous forest (B) 36 cameras and 26 cameras in fragmented with predominance of forest (b) or fragmented with predominance of savanna (s).
We used camera traps of three different brands (Cuddeback, Bushnell, and Moultrie), with similar settings for all cameras: series of three photos with minimum interval between them (max.1 sec), videos $10 \mathrm{sec}$ length, middle LED adjust and maximum sensor of movement activity (Rovero et al. 2013). Cameras were placed on the trees at $60-70 \mathrm{~cm}$ above ground level, with a plastic roof to protect camera from rain. The survey was complemented with opportunistic track records (scratches, caves, excrements, and bones) and interviews conducted in Spanish with the aid of translators among indigenous Pemón people from the local communities. Participation was voluntary and there was no remuneration. Direct and semi-structured interview was used, which have been widely used in investigations of this type (Carvalho et al. 2014). An interviewee was considered reliable if he/she could differentiate local from foreign animals (e. g., Tremarctos ornatus) shown in pictures and drawings (plates of Linares 1998) and if the person has been living in the community on the Gran Sabana for most of his/her life. During the interviews we registered the local names in Arekuna Pemón's dialect.

We identified the species from camera traps and tracks using reference works from Venezuelan (Linares 1998) and the Neotropics (Eisenberg 1989). In addition, mammalogists from the Instituto Venezolano de Investigaciones Científicas were consulted to confirm the identification of 
doubtful records registered by cameras. A representative subset of photos of mammals from this study was deposited on iNaturalist (https://www.inaturalist.org/observations/izolinia).

Basic data analysis. For all species two basic parameters were calculated: an index of frequency of detection (number of detection events for species per 100 days of camera trapping, O'Brien 2011) and naïve occupancy (proportion of all sampling unit with at least one detection of a species, Rovero et al. 2014) in order to have available information to compare with similar studies in Latin America.

Vegetation categorization. For the location of each camera in the sampling unit, we downloaded the time series of Moderate Resolution Imaging Spectroradiometer (MODIS) Vegetation Indices (MOD13Q1) Version 6 with a temporal resolution of 16 days and a spatial resolution of 250 meter (Data source: https://lpdaac.usgs.gov/products/ mod13q1v006/). We used the Normalized Difference Vegetation Index (NDVI) measurements from 2010 to 2018. The time series has 215 total measurements per camera, but we considered only those with good reliability and production quality (approx. $53.6 \%$ ) of the observations (see product user manual in https://lpdaac.usgs.gov/documents/103/ MOD13 User Guide V6.pdf).

As a next step we classified the habitat around each camera using the irregular time series data of reliable NDVI measurements between 2015 and 2018. We performed an unsupervised classification using the partition around medoids method proposed by Kaufman and Rousseeuw (1990). This method uses a mathematical algorithm to identify a subset of observations or "medoids" that represent different combinations of values of the time series, and then calculates the dissimilarity or multivariate distance from all other observations to their closest medoid, these steps are repeated until the algorithm finds the optimal solution with minimum differences within groups and maximum differences between groups. The silhouette width $\left(s_{i}\right)$ is a relative measure of the reliability of the classification for each observation. With this analysis we discriminated three main types of habitat corresponding to "savanna", "forest" and an intermediate "shrub" or "transitional" group (Figure 2).

Analysis of habitat association. We applied the indicator value analysis proposed by Dufrêne and Legendre (1997), which is based on the calculation of fidelity (see definition below) and relative abundance indices for each combination of species and habitat types. In order to apply this analysis, we assumed that species detections are related to abundance and/or activity of individuals and these are in turn indicators of species association with the habitat types identified above. Under these assumption these indices directly assess positive predictive values and sensitivity of the species as bioindicator of particular habitat types in biodiversity monitoring, and is a robust alternative to correlative measures of association (De Cáceres and Legendre 2009).

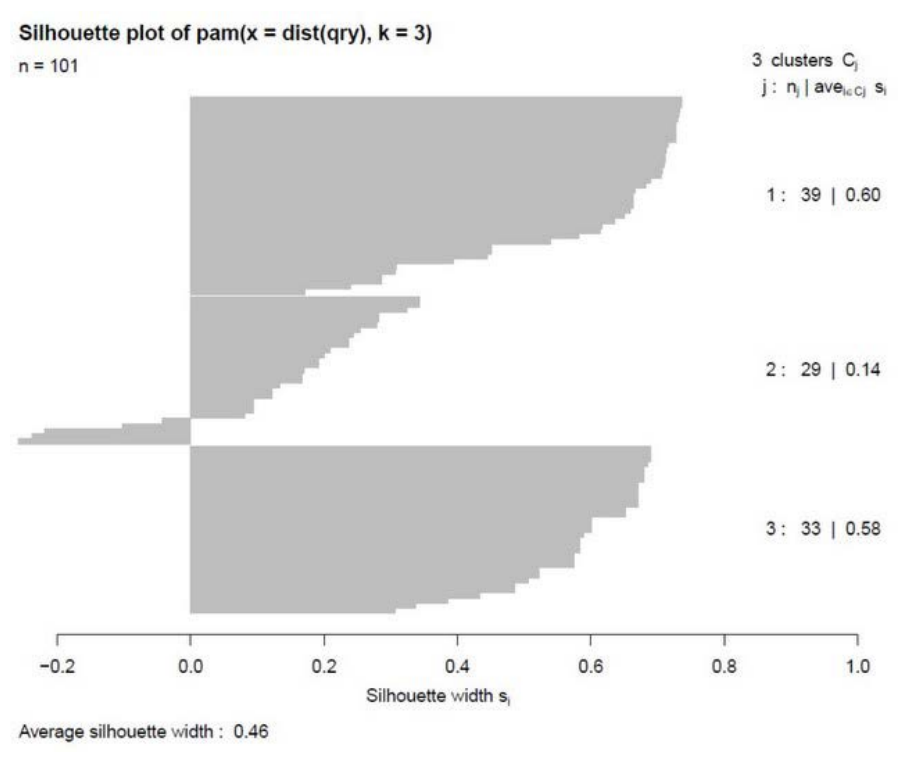

Figure 2. Silhouette plot of the habitat classification.

Here, we consider a detection event as any sequence with less than five minutes difference between consecutive photographs. "Fidelity" is defined as the prevalence of the species in each habitat type (number of different cameras with detection / total number of cameras in the habitat type). Relative abundance (or frequency) is defined as the relative number of detections of each species in each habitat type (number of detections in one habitat type / total number of detections). The "indicator value" (IV) is then calculated for each species/habitat combination as the product of fidelity and relative abundance and can be interpreted as a measure of the strength of the association of one species to a given habitat type. An IV value " 0 " means there is no record of species activity for that habitat type, while and IV value "1" indicates both extensive and exclusive use of the habitat (i. e., it is detected in all cameras in that habitat and never in any other habitat). High values of IV in one habitat mean it must have low IV values in other habitats, thus only the highest IV value is informative for species associations. The significance of the highest IV value is tested by a random permutation procedure of the sites among the habitat types with a bonferroni correction for multiple testing (Legendre and Legendre 2012).

\section{Results}

Effectiveness of camera trapping. Most mammal detections were recorded in blocks with higher forest cover (blocks 3 , 5, 6, 7 and 8, Figure 1). Cameras were installed in 101 sampling unit/period combinations (72 unique cells), achieving a total sampling effort of 5,523 camera*day with 7,569 events. There were 1,010 events with presence of mammal, 351 events with birds and reptiles, and 6,082 empty frames or false positives (camera misfiring, likely. due to vegetation movement or heat, among others, Table 1).

Presence of mammals. We detected 29 species of mammals which belong to eight orders (Table 2). Among the species with the highest values of frequency of detection index and 
naïve occupancy we found: Cuniculus paca, Dasyprocta leporine, and Cerdocyon thous (Table 2). Species with lowest values were Leopardus wiedii, Tayassu pecari, and Leopardus tigrinus. One of the rarest species detected was Speothus venaticus, with one record. Additional evidence of mammal presence was recorded from scratches, caves, tracks, excrements and bones, with a total of 193 records of 20 species (Table 2). Cerdocyon thous were more frequent, with 37 records. During semi-structured interviews with 29 local dwellers (three women and 26 men, with average familiar nucleus 6.5 person) from the Pemón communities, the majority of species from camera trap were recognized (Table 2), but $P$. maximus and $S$. venaticus were only recognized by older interviewees.

Habitat categorization. The categorization of vegetation group of savanna (group 1) and forest (group 3 ) is well differentiated (the average sillhoutte width is large, all $s_{i}>0$ ), while for shrub-intermediate vegetation (group 2) some observations lay between different groups and might have been misclassified (the average sillhoutte width is low and, some $s_{i}<0$, Figure 2).

We show the NDVI values for the camera locations classified for each vegetation group (Figure 3 ). The NDVI value for savanna group is mostly between 0.4 and 0.7 , with some seasonal observations below 0.4 (beginning of 2015 and 2016, but not evident in 2017, Figure 3a) and forest is above 0.8 for most of the year with some isolated observation are below this value (Figure 3c). The shrub - transitional habitat has intermediate (values of NDVI (0.5 to 0.9; Figure $3 \mathrm{~b}$ ), but they are frequently below 0.8 (value for forest group). In some localities the NDVI values might be closer to the forest habitat (localities with negative silhouette width in Figure 2).

Habitat association. We found significant associations for 10 species out of 25 species analysed (Table 3): seven spe-

Table 1. Effectiveness of camera trapping. Continuous forest (F), fragmented with predominance of forest (f), fragmented with predominance of savanna (s) and savanna (S), transitional (trans.)

\begin{tabular}{|c|c|c|c|c|c|c|c|c|}
\hline \multirow[b]{2}{*}{$\frac{\check{Y}}{\infty}$} & \multirow[b]{2}{*}{ 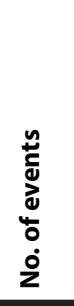 } & \multirow[b]{2}{*}{ 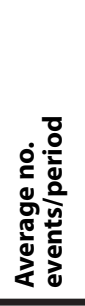 } & \multicolumn{3}{|c|}{$\begin{array}{l}\text { Number of species } \\
\text { register in each } \\
\text { habitat }\end{array}$} & \multicolumn{3}{|c|}{$\begin{array}{l}\text { Number of cameras } \\
\text { in each habitat }\end{array}$} \\
\hline & & & $\begin{array}{l}\breve{y} \\
\grave{0}\end{array}$ & 这 & 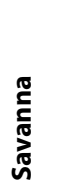 & $\begin{array}{l}\breve{y} \\
\dot{y} \\
\dot{4}\end{array}$ & 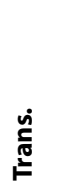 & 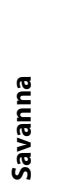 \\
\hline 1 & 19 & 6 & - & 1 & 7 & - & 1 & 14 \\
\hline 2 & 39 & 13 & - & 7 & 7 & - & 4 & 9 \\
\hline 3 & 208 & 69 & 18 & 13 & - & 13 & 1 & - \\
\hline 4 & 154 & 51 & 13 & 15 & - & 11 & 4 & - \\
\hline 5 & 197 & 66 & 6 & 18 & 2 & 4 & 7 & 4 \\
\hline 6 & 205 & 68 & 8 & 13 & 6 & 4 & 6 & 4 \\
\hline 7 & 89 & 89 & 10 & 5 & - & 3 & 1 & - \\
\hline 8 & 88 & 88 & - & 10 & - & - & 4 & - \\
\hline 9 & 4 & 4 & - & 3 & 1 & - & 1 & 3 \\
\hline 10 & 7 & 7 & - & 2 & 1 & & 1 & 2 \\
\hline Total & 1010 & & & & & 35 & 30 & 36 \\
\hline
\end{tabular}
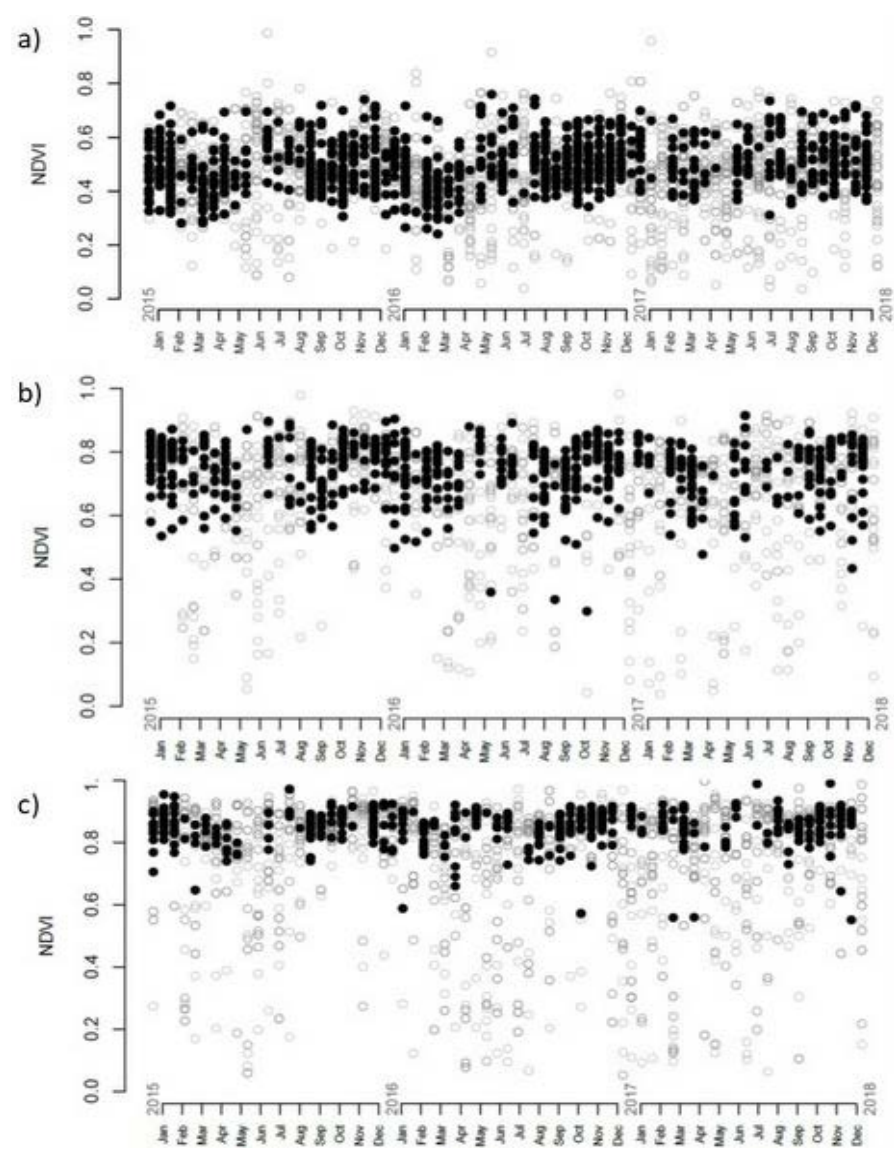

Figure 3. NDVI values for habitat type a) savanna b) intermediate/shrub habitat type c) forest. Dark filled dots represent reliable, good quality measurements used in the analysis, and grey circles represent unreliable or low quality measurements.

cies in forest two in intermediate/shrub habitat and one in savanna. Thirteen species have high relative frequency in forest (values equal or above 0.5 ), but fidelity was highly variable (ranging from 0.064 to 0.645 ). Combining both indices leaves only seven species with statistical significant association to forest (indicator value equal or above 0.161 and $P<0.05)$ : Dasypus kappleri, D. leporina, Mazama americana, Mazama gouazoubira, N. nasua, P.maximus, and T. terrestris.

\section{Discussion and Conclusions}

Savanna vs. forest species. Existing data on species presence on GS is mostly based on non-systematic survey, while our study provides for the first time quantitative data to test common assumptions on animal habitat preference in this region (Ochoa et al. 1993; Table 3). Cerdocyon thous is present in different types of vegetation from forest to marshland and savanna, but has preference for savanna (Lucherini 2015) and $49 \%$ of specimens collected by the Smithsonian Venezuelan Project were sampled in savanna habitat. In our sample, this was the only species not detected in forest habitat and showing a significant preference for savanna habitat (Table 3). Odocoileus virginianus and Tamandua tetradactyla have been recorded in a range of habitats (Ochoa et al. 1993), but our data suggested a strong (but not significant) association with savanna (Table 3). Nasua nasua, $P$. maximus, and D. marsupialis showed a strict preference 
Table 2. Nonvolant medium and large mammal species recorded in the present report including its names in Arekuna (Pemón dialect), detection frequency, naïve occupancy, status of Red List (RL) following Rodríguez and Rojas-Suárez (2008) and survey method: CT: camera trapping, TRK: tracking, INT: interviews with local Pemón communities.$$
\text { I }\|\|\|\|=\|
$$

ARTIODACTYLA

Cervidae

Mazama americana

Mazama gouazoubira

Odocoileus virginianus

Tayassuidae

Pecari tajacu

Tayassu pecari

CARNIVORA

Felidae

Leopardus wiedii

Leopardus tigrinus

Leopardus pardalis

Panthera onca

Puma concolor

Canidae

Cerdocyon thous

Speothos venaticus

Mustelidae

Eirabarbara

Nasua nasua

CINGULATA

Dasypodidae

Dasypus kappleri

Dasypus novemcinctus

Cabassous unicinctus

Priodontes maximus

PERISSODACYLA

Tapiridae

Tapirus terrestris

DIDELPHIMORPHIA

Didelphidae

Didelphis imperfecta

Didelphis marsupialis

PILOSA

Myrmecophagidae

Tamandua tetradactyla

Myrmecophaga tridactyla wareme

woiwo

\section{kaukau}

kaukan

temenen

kusariwara

maikan

daiyai

yeruena

kuachi

muruk

$\begin{array}{lll}47 & 23 & 0.18\end{array}$

$\begin{array}{lll}4 & 2 & 0.02\end{array}$

mauraimu

$\begin{array}{lll}9 & 1 & 0.02\end{array}$

$0.21 \quad \mathrm{LC}$

0.04 LC

CT, TRK

$\mathrm{CT}, \mathrm{TRK}$, INT

CT

0.11 EN CT, TRK, INT

RODENTIA

Cuniculidae

Cuniculus paca

Dasyproctidae

Dasyprocta leporina

(n)

Myoprocta pratti

akuri

Hydrochoerinae

Hydrochoerus hydrochaeris

parwena

PRIMATES

Cebidae

Cebus olivaceus

ibarakao

8

0.07

$0.09 \quad$ LC

CT, TRK, INT

Atelidae

Alouatta macconnelli*

arauta

LC TRK, INT to forest habitat, and were not found in savanna or shrub - intermediate habitat. Nasua nasua and P. maximus have decreasing population trends due to loss of undisturbed primary rain forest habitats (Anacleto et al. 2014; Emmons and Helgen 2016), moreover P. maximus is considered an endangered species in Venezuela (Rodríguez and RojasSuárez 2008). Among all mammal species associated to forest group of vegetation (13 species), $D$. imperfecta, $D$. leporia, D. novemcinctus, and $M$. tridactyla were also found in savanna. The importance of shrub-intermediate habitat needs to be recognized as the majority of species (21) were detected in this habitat with exception of three forest and one savanna species. Two unexpected results might be related to artefacts of not considering the effect of imperfect detectability. Didelphis marsupialis was only detected on three occasions in forest habitat in the study area, but this species is usually tolerant to a wide variety of habitats (Astúa de Moraes et al. 2019). On the other hand, C. paca is known to occur in a wide range of forest types in moist areas (Emmons 2016) but showed strong association to shrub-intermediate habitat in our study area. The large number of detections of this species (343 records) might result from high abundance (number of individuals) and/ or high activity of a limited number of individual due to seasonal availability of resources, but in either case, this results indicate the relative regional importance of this habitat for this species.

A baseline for long term monitoring in GS. Our study represents the first large scale quantitative effort to sample the medium and large mammal fauna in the GS, confirming that camera traps play an important role in monitoring biodiversity. We were able to detect $90 \%$ of expected species of medium and large mammals (Lew et al. 2009) and propose new approach to calculate habitat preferences that can be successfully replicate in other parts of GS and among mammals and other animals. The main challenges are related to the detection in open areas such as savanna and undetected or real absences of rare or elusive species. Although shorter monitoring periods are cheaper and easier, they also have lower probability of detecting all the species present in an area (Si et al. 2014), especially considering seasonal activity patterns. Here, we established a base line for long term monitoring in the Gran Sabana confirming the sampling effort and study design required to reach monitoring long-term goals. Finally, we have highlighted the importance of this baseline given the expected intensification of threats in the South of Venezuela. Human encroachment has already marked significant deforestation in Canaima NP being one of the most important threat for biodiversity. This study represents a good opportunity to describe effective and exhausting survey in changing vegetation conditions that is transformed into the base line for monitoring.

Inventory of large and medium mammals in the Gran Sabana. Our results demonstrate high effectiveness of 
camera traps for the inventory of large and medium-sized terrestrial mammals in GS. Earlier camera trap studies in South America were limited by logistic (cost of deployment) or low efficiency (few records per sampling effort; Tobler et al. 2008), but notable advances have been made and camera trapping has now become a preferred technique for the efficient survey of medium and large mammals in long term and large scale research. While some regions have been studied extensively with impressive results (Lima et al. 2017), many areas remain under-sampled. Our sampling design showed good performance when compared with other South America studies with similar sampling effort and study area size (Table 4), including two published camera-trap studies of mammal communities in Venezuela (Perera-Romero et al. 2015; Morán et al. 2018). Although camera traps studies are often complemented by other methods, in our case almost all target species detected by tracks and interviews were also detected by cameras, except for Alouatta macconnelli. Also, during interviews members of Pemón community have not recognized different species of opossum, Armadillo (except P. maximus), and small felids like Leopardus wiedii. In other cases, they mentioned in the interviews that in the $60 \mathrm{~s}$ and $70 \mathrm{~s}$ S. venaticus were commonly observed in the area, while currently they are not observed, probably due to forest cover change. This canid is an elusive species with few records in Venezuela, probably due to low abundance or local extinction (Rodríguez and Rojas-Suárez 2008). The reference results of this first sampling effort can serve as a guide for optimizing future sampling. For example, in similar studies, species accumulation curves (Ferrer Paris et al. 2013; Si et al. 2014) suggests that sampling could be more effective with larger number of traps and shorter duration rather than with fewer traps and larger duration of sampling (due to low turnover between sampling periods), this would require a larger investment in equipment, but reduced costs of field work.

Drawback from the present sampling need to be considered when designing improved future monitoring programs. Special attention must be given to the lack of detection of expected species, which might reflect either limitations of sampling or real ecological patterns, or limitations of this technique in areas of open vegetation.

Challenge of camera trapping in open areas. The success of camera trapping in the open habitats like savannas is limited. In Thaba Tholo Wilderness Reserve, South Africa cameras took photos of large carnivores (jackal, brown hyena or leopard), but underestimated the presence of small carnivores, for which tracking was a more appropriate technique (Pirie et al. 2016). During this study, despite of intense sampling effort on savanna (Table 1), false positives were most frequently recorded in savanna than in forest, which may be caused by the movement of grasses in open areas, exposed to wind. Additionally, rocks heated up by solar radiation can activate the camera sensors. Savanna cameras seemed less effective than cameras in forests, as fewer records of mammals' species
Table 3. Habitat association of mammals in the study in comparison with Ochoa et al. (1993): Fl (lowland forest), Fm (montane forest), B (bush), Sa (savannas) and habitat presence: - savanna, I - shrub-intermediate habitat and F- forest.

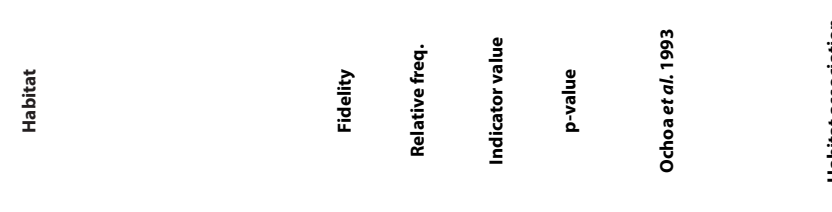

\begin{tabular}{|c|c|c|c|c|c|c|}
\hline \multicolumn{7}{|l|}{ Sabana } \\
\hline Cebus olivaceus & 0.11 & 0.43 & 0.05 & 0.91 & $\mathrm{Fl}, \mathrm{Fm}$ & $\mathrm{S}, \mathrm{I}, \mathrm{F}$ \\
\hline Cerdocyon thous & 0.56 & 0.65 & 0.36 & $0.00^{*}$ & $\mathrm{Fl}, \mathrm{Fm}, \mathrm{B}, \mathrm{Sa}$ & $\mathrm{S}, \mathrm{I}$ \\
\hline Hydrochoerus hydrohaeris & 0.06 & 0.68 & 0.04 & 0.66 & $\mathrm{Fl}, \mathrm{Sa}$ & $\mathrm{S}, \mathrm{I}$ \\
\hline Odocoileus virginianus & 0.11 & 0.84 & 0.09 & 0.18 & $\mathrm{Fl}, \mathrm{Fm}, \mathrm{B}, \mathrm{Sa}$ & $\mathrm{S}$ \\
\hline Tamandua tetradactyla & 0.11 & 0.43 & 0.05 & 0.76 & $\mathrm{Fl}, \mathrm{Fm}, \mathrm{B}, \mathrm{Sa}$ & $\mathrm{S}, \mathrm{I}, \mathrm{F}$ \\
\hline \multicolumn{7}{|l|}{ Forest } \\
\hline Didelphis. imperfecta & 0.16 & 0.60 & 0.10 & 0.47 & $\mathrm{Fl}, \mathrm{Fm}, \mathrm{B}$ & $\mathrm{S}, \mathrm{I}, \mathrm{F}$ \\
\hline Dasypus kappleri & 0.42 & 0.91 & 0.38 & $0.00^{*}$ & $\mathrm{FI}$ & $\mathrm{I}, \mathrm{F}$ \\
\hline Dasyprocta. leporina & 0.65 & 0.57 & 0.37 & $0.02^{*}$ & $\mathrm{Fl}, \mathrm{Fm}, \mathrm{B}$ & $\mathrm{S}, \mathrm{I}, \mathrm{F}$ \\
\hline Didelphis. marsupialis & 0.06 & 1.00 & 0.06 & 0.35 & $\mathrm{Fl}, \mathrm{Fm}, \mathrm{B}$ & $\mathrm{F}$ \\
\hline Dasypus novemcinctus & 0.26 & 0.57 & 0.15 & 0.29 & $\mathrm{Fl}, \mathrm{Fm}, \mathrm{B}$ & $\mathrm{S}, \mathrm{I}, \mathrm{F}$ \\
\hline Eira barbara & 0.29 & 0.50 & 0.14 & 0.30 & $\mathrm{Fl}, \mathrm{Fm}$ & $\mathrm{I}, \mathrm{F}$ \\
\hline Mazama americana & 0.32 & 0.78 & 0.25 & $0.03^{*}$ & $\mathrm{Fl}, \mathrm{Fm}, \mathrm{B}$ & $\mathrm{I}, \mathrm{F}$ \\
\hline Mazama gouazoubira & 0.61 & 0.84 & 0.52 & $0.00^{*}$ & $\mathrm{Fl}, \mathrm{Fm}, \mathrm{B}$ & $\mathrm{I}, \mathrm{F}$ \\
\hline Myrmecophaga tridactyla & 0.26 & 0.55 & 0.14 & 0.33 & $\mathrm{Fl}, \mathrm{Fm}, \mathrm{B}, \mathrm{Sa}$ & $\mathrm{S}, \mathrm{I}, \mathrm{F}$ \\
\hline Nasua nasua & 0.16 & 1.00 & 0.16 & $0.05^{*}$ & $\mathrm{Fl}, \mathrm{Fm}, \mathrm{B}, \mathrm{Sa}$ & $\mathrm{F}$ \\
\hline Priodontes maximus & 0.19 & 1.00 & 0.19 & $0.01 *$ & $\mathrm{Fl}, \mathrm{Fm}$ & $\mathrm{F}$ \\
\hline Pantera onca & 0.23 & 0.52 & 0.12 & 0.30 & $\mathrm{Fl}, \mathrm{Fm}$ & $\mathrm{I}, \mathrm{F}$ \\
\hline Tapirus terrestris & 0.23 & 0.89 & 0.20 & $0.03^{*}$ & $\mathrm{Fl}, \mathrm{Fm}, \mathrm{B}$ & $\mathrm{I}, \mathrm{F}$ \\
\hline \multicolumn{7}{|l|}{ Shrub/intermediate } \\
\hline Cuniculus paca & 0.63 & 0.63 & 0.40 & $0.03^{*}$ & $\mathrm{Fl}, \mathrm{Fm}$ & $\mathrm{S}, \mathrm{I}, \mathrm{F}$ \\
\hline Cabassous unicinctus & 0.05 & 0.62 & 0.03 & 0.84 & $\mathrm{Fl}, \mathrm{Fm}, \mathrm{B}, \mathrm{Sa}$ & $\mathrm{I}, \mathrm{F}$ \\
\hline Leopardus pardalis & 0.37 & 0.61 & 0.22 & $0.05^{*}$ & $\mathrm{Fl}, \mathrm{Fm}$ & $\mathrm{S}, \mathrm{I}, \mathrm{F}$ \\
\hline Leopardus wiedii & 0.05 & 0.62 & 0.03 & 0.85 & $\mathrm{Fl}, \mathrm{Fm}$ & $\mathrm{I}, \mathrm{F}$ \\
\hline Puma concolor & 0.26 & 0.58 & 0.15 & 0.10 & $\mathrm{Fl}, \mathrm{Fm}, \mathrm{B}, \mathrm{Sa}$ & $\mathrm{S}, \mathrm{I}, \mathrm{F}$ \\
\hline Pecari tajacu & 0.05 & 0.62 & 0.03 & 0.86 & $\mathrm{Fl}, \mathrm{Fm}, \mathrm{B}, \mathrm{Sa}$ & $\mathrm{I}, \mathrm{F}$ \\
\hline Tayassu pecari & 0.05 & 0.62 & 0.03 & 0.86 & $\mathrm{FI}$ & $\mathrm{I}, \mathrm{F}$ \\
\hline
\end{tabular}

were obtained in savanna and some species occupying typically herbaceous and savanna ecosystem like $P$. yagouaroundi and Cavia aperea were not detected at all. On the other hand, not sampling savanna habitats with camera traps can generate gaps of knowledge. Other sampling techniques should be considered as well, such as observation with drones, genetic tagging, or more traditional tracks stations and marks studies.

Undetected species or real absences? Our study detected a great number of species, when compared with other camera trap studies in South America, yet it did not record all 


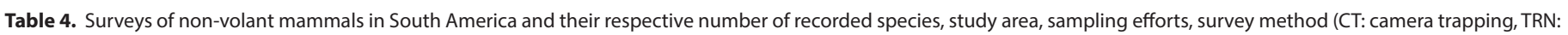
transect, TRK: tracking, INT: interviews and references, LT: literature).

\begin{tabular}{|c|c|c|c|c|c|}
\hline Location & Study area $\left(\mathbf{k m}^{2}\right)$ & Sampling effort & No. mammals species & Survey method & Reference \\
\hline Cerrado, Brazil & 87 & 2,340 camera day & 17 & CT & Cabral et al. (2017) \\
\hline Cerrado, Brazil & 17 & 450 camera day & 14 from $\mathrm{CT}$ ( 18 in total) & CT,TRK, TRN, INT & Trolle (2007) \\
\hline Central Surinam & 324 & $1,905^{*}$ & 28 & CT & Ahumada et al. (2011) \\
\hline Amazonas, Peru & 50 & 3780 camera day** & 28 & CT & Tobler et al. (2008) \\
\hline Pantanal, Brazil & 20 & 450 camera day & 18 with $\mathrm{CT}$ ( 30 in total) & $\mathrm{CT}, \mathrm{TRK}, \mathrm{TRN}, \mathrm{INT}$ & Trolle (2003a) \\
\hline Rio Negro, Brazil & 1,500 & 750 records & 14 with $\mathrm{CT}(42$ in total) & $\mathrm{CT}$, TRK, TRN & Trolle (2003b) \\
\hline Atlantic forest, Brazil & 170 & 25,512 hours of camera trap & 16 with $\mathrm{CT}$ ( 58 in total) & $C T, T R K, T R N, L T$ & Rocha-Mendes et al. (2015) \\
\hline Rio Caura, Venezuela & 821 & 5,661 camera day & 20 & $\mathrm{CT}, \mathrm{INT}$ & Perera-Romero et al. (2015) \\
\hline Burro Negro, Venezuela & 54 & 1,799 camera day & 20 with $\mathrm{CT}$ ( 40 in total) & $\mathrm{CT}, \mathrm{TRK}, \mathrm{INT}$ & Morán et al. (2018) \\
\hline Gran Sabana, Venezuela & 1,442 & 5,523 camera day & 29 & $\mathrm{CT}, \mathrm{TRK}, \mathrm{INT}$ & This study \\
\hline
\end{tabular}

* Number of sampling days for each camera summed for all the cameras at the site

** 1,440 (2005) and 2,340 (2006) camera day

species expected in the area (Table 2; Ochoa 2001; Lew et al. 2009). This difference can be due to (a) low detection probability of elusive species, (b) low abundance or local extinction; or (c) real absence of the species. Among the six species of the family Felidae in Venezuela, only the $P$. yagouaroundi remains undetected, possibly due to low detectability, as it is much less common than previously suspected, having overall negative population trends (Caso et al. 2015). From the family Mustelidae, Galictis vittata and Mustela frenata were expected, but not detected in the study. Confirmed records of $G$. vittata are scarce across its distribution, therefore no current accurate estimates of its distribution are available (Cuarón et al. 2016). M. frenata favoured habitats include brushland and open woodlands, field edges, riparian grasslands, swamps, and marshes (Helgen and Reid 2016) that were not particularly sampled in this study. Also, Marmosops parvidens (Didelphidae) was not detected, either due to its preference for humid habitats in primary and secondary tropical forests, including well drained and swampy forests that were not sampled, or due to low detection probability (Martin 2016). Among the rodents, C. aperea was not detected, despite of extensive sampling effort on savanna that is its allegedly preferred habitat. We also provide a new confirmed record for Myoprocta pratii inside Canaima NP at the limits of its distribution range (previously only known from park surroundings; Lew et al. 2009).

Interestingly, there were no camera or track observation of Sylvilagus brasiliensis, which is usually a common species within its range and should be recorded by camera traps. Interviewed Pemón do not recognize this species for their region, but they do know it from other regions of Venezuela. Traditionally, S. brasiliensis has been considered a widely distributed species, with large information gaps in the Amazon region (Chapman and Hockman 1980). Its presence in GS is disputed because of the lack of collection or museum records (Eisenberg 1989; Ochoa et al. 1993; Linares 1998; Lord 1999; Huber et al. 2001; Lew et al. 2009). Recent publications (Ruedas et al. 2017) question the identity of the different populations of S. brasiliensis, suggesting that instead of a species with great ecological adaptability, there may be more than 37 different taxa, for which distribution or ecology are not yet fully understood. Thus, the records of the lagomorphs in GS can have important biogeographic and ecological implications. Additional interviews in other parts of GS and the Canaima community inside Canaima NP (I. Stachowicz, personal observation), seem to confirm that the species is not found in GS. Therefore, we suggest that $S$. brasiliensis is the only real absence and should be removed from the list of species of GS and Canaima NP.

Challenges and opportunities for conservation. The timing of our study coincided with a complex socio-economic context, which represents a great challenge for conservation in the country. Sampling in the Kavanayen region was limited to a single period in 2018 because the deterioration of general conditions in Venezuela, lack of fuel or food supply, mining encroachment and thus elevated military presence in the region, increased sampling cost and compromised personal security. Yet this situation makes this first sampling even more valuable as a reference of the conditions close to the onset of one of the largest mining development plans in South America.

The development plans of the OMA have raised serious concern about the future of different forest formations and its fauna along the Orinoco River, the Guiana Shield ecosystems and National Parks like Canaima that historically had low exposure to threats. During interviews, the leaders of Pemón communities expressed interest in rescuing traditional knowledge that might be at risk due to changing livelihoods in the region. Young people are migrating to work in profitable, yet mostly illegal, economic activities like mining and timber extraction, and altering their relationship with their natural heritage (Herrera and Rodríguez 2015). The Canaima National Park, as a UNESCO Heritage site generates important income opportunities for indigenous people, however international tourism has been declining in recent years (I. Stachowicz, per. Obs.).

Lack of proactive management plans for OMA, regulation and enforcement to mitigate and restore impacts 
on ecosystems and society under severe stress from OMA result in uncontrolled deforestation and erosion degrading watersheds in the Orinoco and Yuruani basins. Management of protected areas within the OMA will play a key role in determining how these threats will affect the different forest formations in southern Venezuela (Ferrer-Paris et al. 2019). Therefore, effective and concrete conservation action is needed, even large "paper parks" will not be enough.

Moreover, the presence of six endangered species in the study area represents a good opportunity for conservation action (Table 2). In Venezuela, P. maximus has been classified as Endangered (Rodríguez and Rojas-Suárez 2008) and is considered an emblematic native species. P. maximus can play an important role as an ecosystem engineer through their excavation activity that may be of high value to the community of vertebrates (Desbiez and Kluyber 2013) but has been little studied due to its fossorial and highly cryptic nature (Silveira et al. 2009). During this study, P. maximus was detected eight times in six different localities and we suggest using this data to design specific surveys for abundance estimation including a combination of techniques such as radiotagging, burrow surveys and camera-trapping.

Conservation programs in the region need to combine educational and social action that consider natural resources management and alternative, non-extractive livelihoods. Non-consumptive recreation combined with citizen science monitoring could support long-term monitoring of protected and unprotected area that is useful for park authorities for more detailed surveys of local fauna (Kays et al. 2017). Undoubtedly, this strategy needs to be adjusted to Venezuelan conditions but could offer new, possible income for local communities from tourism and better opportunities for monitoring illegal activities.

\section{Acknowledgements}

We especially thank to Pemón communities in la Gran Sabana: Kawi, Uroy-Uaray, Wuarapata, Kavanayen and their leaders H. Chani, N. Blanco, M. Castro, A. Blanco, N. Castro and my guides $C$. Velasquez and Efiel. Many thanks to $\mathrm{H}$. Rodriguez and J. Leon who facilitate the research station Parupa of Corporacion Venezolana de Guayana (CVG) for collaboration in the project and were very helpful to organize the fieldwork. Especially thanks to G. Buitron-Jurado who provided important taxonomic comments and $\mathrm{N}$. Noriega for linguistic revision. Financial support provided Idea Wild foundation and Finca Dos Aguas managed by Eduardo Stain. Project received permits from Ministerio del Poder Popular para Ecosocialismo y Aguas 1419/3/33/2015 and Instituto Nacional de Inparques 18/16 205, 156, 17.

\section{Literature cited}

Ahumada, J. A., C. E. F. Silva, K. Gajapersad, C. Hallam, J. Hurtado, E. Martin, A. Mcwilliam, B. Mugerwa, T. O’brien, F. Rovero, D. Sheil, W. R. Spironello, N. Winarni, and S. J. Andelman. 2011. Community structure and diversity of tropical forest mammals: Data from a global camera trap network. Philosophical Transactions of the Royal Society B. Biological Sciences 366:2703-2711.

Allan, J. R., O. Venter, S. Maxwell, B. Bertzky, K. Jones, Y. Shi, And J. E. M . Watson. 2016. Recent increases in human pressure and forest loss threaten many Natural World Heritage Sites. Biological Conservation 206: 47-55.

Anacleto, T. C. S., F. Miranda, I. Medri, E. Cuellar, A. M. Abba, And M. Superina. 2014. Priodontes maximus. The IUCN Red List of Threatened Species 2014: e.T18144A47442343. Downloaded on 25 May 2019.

Astúa de Moraes, D., D. Lew, L. P. Costa, And R. Pérez-Hernandez. 2016. Didelphis marsupialis. The IUCN Red List of Threatened Species 2016: e.T40501A22176071. Downloaded on 25 May 2019.

Cabral, R., M. Zanin, G. Porfírio, and D. Brito. 2017. Mediumsized to large mammals of Serra do Tombador, Cerrado of Brazil. Check List 13:21-29.

Carvalho, M., J. M. Palmeirim, F. C. Rego, N. Sole, A. Santana, AND J. E. FA. 2014. What motivates hunters to target exotic or endemic species on the island of São Tomé, Gulf of Guinea? Oryx 49:1-9.

Caso, A., de Oliveira, T., and S. V. Carvajal. 2015. Herpailurus yagouaroundi. The IUCN Red List of Threatened Species 2015:e.T9948A50653167. Downloaded on 24 May 2019.

Chapman, J., A., AND J. G. Hockman. 1980. Sylvilagus floridanus. Mammalian species 136:1-8.

Cove, M. V., R. M. Spinola, V. L. Jackson, J. C. Saenz, and O. CнAssot. 2013. Integrating occupancy modelling and camera-trap data to estimate medium and large mammal detection and richness in a Central American biological corridor. Tropical Conservation Science 6:781-795.

Cuarón, A. D., F. Reid, J. F. González-Maya, And K. Helgen. 2016. Galictis vittata. The IUCN Red List of Threatened Species 2016:e.T41640A45211961. Downloaded on 24 May 2019.

De Cáceres, M., and P. Legendre. 2009. Associations between species and groups of sites: indices and statistical inference. Ecology 90:3566-3574.

Desbiez, A. L. J., And D. Kluyber. 2013. The role of giant armadillos (Priodontes maximus) as physical ecosystem engineers. Biotropica 45:537-540.

Dufrêne, M., AND P. Legendre. 1997. Species assemblages and indicator species: the need for a flexible asymmetrical approach. Ecological Monographs 67:345-366.

EISENBERG, J. F. 1989. Mammals of the Neotropics. University of Chicago Press. Chicago, U.S.A.

Emmons, L. 2016. Cuniculus paca. The IUCN Red List of Threatened Species 2016:e.T699A22197347. Downloaded on 25 May 2019.

Emmons, L., AND K. Helgen. 2016. Nasua nasua. The IUCNRed List of Threatened Species 2016:e.T41684A45216227. Downloaded on 25 May 2019.

ESRI. 2014. ArcGIS desktop: release 10.3. Environmental Systems Research Institute, Redlands, U.S.A.

Ferrer-Paris, J. R., Sánchez-Mercado, A., And J. P. Rodríguez. 2013. Optimización del muestreo de invertebrados tropicales: Un ejemplo con escarabajos coprófagos (Coleoptera: Scarabaeinae) en Venezuela. Revista de Biología Tropical 61:89-110.

Ferrer-Paris, J. R., Zager, I., Keith, D. A., Oliveira-Miranda, M. A., Rodríguez, J. P., Josse, C., González-Gil, M., Miller, R. M., Zambrana-Torrelio, C., And E. Barrow. 2019. An ecosystem 
risk assessment of temperate and tropical forests of the Americas with an outlook on future conservation strategies. Conservation Letters, 12:e12623.

Handley, C. O., JR. 1978. Mammals of the Smithsonian Venezuelan Project, Brigham Young University Science Bulletin. Biological Series 20: 1-85.

Helgen, K., and F. Reid. 2016. Mustela frenata. The IUCN Red List of Threatened Species 2016: e.T41654A45213820. Downloaded on 24 May 2019.

Herrera, F. F., and I. Rodríguez. 2015. Minería de oro en Venezuela: luchas simbólicas vs políticas redistributivas. Ecología Política 1:85-88.

Hoppe-Dominik, B., H. S. KüHL, G. RadL, and F. Fischer. 2011. Long-term monitoring of large rainforest mammals in the biosphere reserve of Taï National Park, Côte d'Ivoire. African Journal of Ecology 49:450-458.

Huber, O., G. Febres, and H. Arnal. 2001. Ecological Guide to the Gran Sabana - Canaima National Park - Venezuela. Editorial Arte. Caracas, Venezuela.

Huber, O., ANd M. N. Foster. 2003. Conservation priorities for the Guayana Shield. Conservation International. Washington, U.S.A.

Kaufman, L. R., AND P. Rousseeuw. 1990. Finding groups in data: An introduction to cluster analysis. John Wiley and Sons Inc. Hoboken, U.S.A.

Kays, R., A. W. Parsons, M. C. Baker, E. L. Kalies, T. Forrester, R. Costello, AND W. J. McShea. 2017. Does hunting or hiking affect wildlife communities in protected areas? Journal of Applied Ecology 54:242-252.

Lew, D., B. Rivas, H. Rojas, and A. Ferrer. 2009. Mamíferos del Parque Nacional Canaima. Pp. 41-75 in Biodiversidad del Parque Nacional Canaima: bases técnicas para la conservación de la Guayana venezolana (Senaris, J. C., D. Lew, and C. Lasso, eds.). Fundación La Salle de Ciencias Naturales y The Nature Conservancy. Caracas, Venezuela.

Legendre, P., and L. Legendre. 2012. Numerical Ecology (3rd Edition). Elsevier. Amsterdam, The Netherlands.

Lim, B. K., M. D. ENGSTROM, AND J. OchOA. 2005. Mammals. Mammals Bulletin of the Biological Society of Washington 13:77-92.

Lima, F., G. Beca, R. de Lara Muylaert, C. N. Jenkins, M. L. L. Perilli, A. M. de Oliveira, R. L. Massara, A. P. Paglia, A. G. Chiarello, M. E. Graipel, J. J. Cherem, A. L. Regolin, L. G. R. Oliveira Santos, C. R. Brocardo, A. Paviolo, M. S. Di Bitetti, L. M. Scoss, F. L. Rocha, R. Fusco-Costa, C. A. Rosa, M. X. da Silva, L. Hufnagel, P. M. Santos, G. T. Duarte, L. N. Guimaräes, L. I. Bailey, F. H. Guimaräes Rodrigues, H. M. Cunha, F. Morel Fantacini, G. $\mathbf{O}$. Batista, J. A. Bogoni, M. A. Tortato, M. R. Luiz, N. Peroni, P. V. de Castilho, T. B. Maccarini, V. Picinatto Filho, C. De Angelo, P. Cruz, V. Quiroga, M. E. Iezzi, D. Varela, S. M. C. Cavalcanti, A. C. Martensen, E. V. Maggiorini, F. F. Keesen, A. Valle Nunes, G. M. Lessa, P. Cordeiro-Estrela, M. G. Belträo, A. C. F. de Albuquerque, B. Ingberman, C. R. Cassano, L.C. Junior, M. C. Ribeiro, AND M. Galetti. 2017. ATLANTIC-CAMTRAPS: a dataset of medium and large terrestrial mammal communities in the Atlantic Forest of South America. Ecology 98:2979.

Linares, O. J. 1998. Mamíferos de Venezuela. Sociedad Conservacionista Audubon de Venezuela. Caracas, Venezuela.

LoRD, R. D. 1999. Wild mammals of Venezuela. Armitano Editores, Caracas, Venezuela.
LuCHerINI, M. 2015. Cerdocyon thous. The IUCN Red List of Threatened Species 2015:e.T4248A81266293. Downloaded on 25 May 2019.

Lyra-Jorge, M. C., G. Ciocheti, and V. R. Pivello. 2008. Carnivore mammals in a fragmented landscape in northeast of Sao Paulo State, Brazil. Biodiversity and Conservation 17:1573-1580.

Martin, G. M. 2016. Marmosops parvidens. The IUCN Red List of Threatened Species 2016:e.T12824A22178960. Downloaded on 24 May 2019.

Morán, L., L. García, J. D. Ferrebuz, R. Sánchez, A. SánchezMercado, A. Porta, and J. R. Ferrer-Paris. 2018. Interannual and daily activity patterns of mid-sized mammals in Maracaibo Lake Basin, Venezuela. Therya 9:227-236.

O'Brien, T. G. O. 2011. Abundance, density and relative abundance: a conceptual framework. Pp.71-96 in Camera traps in animal ecology. Methods and analyses (O'Connell, A. F., J. D. Nichols, and U. K. Karanth, eds.). Springer. New York, USA.

OchoA, J. 2001. Mammals. Pp.192 in Ecological Guide to the Gran Sabana - Canaima National Park - Venezuela (Huber, O., G. Febres, and H. Arnal, eds.). Editorial Arte. Caracas. Venezuela.

OChoA, J., C. Molina, and S. Giner. 1993. Inventario y estudio comunitario de los mamíferos del Parque Nacional Canaima, con una lista de las especies registradas para la Guayana venezolana. Acta Científica Venezolana 44:245-262.

Perera-Romero, L., J. Polisar, and L. Maffel. 2015. Grandes vertebrados terrestres en tierras ancestrales indigenas del alto Caura: importancia de los acuerdos comunitarios para la conservación del Escudo Guayanes venezolano. Pp. 185-204 in Conservacion de grandes vertebrados en areas no protegidas de Colombia, Venezuela y Brasil (Payan E., C. A. Lasso, and C. Castano-Uribe, eds.). I Serie Editorial Fauna Silvestre Neotropical. Instituto de Investigacion de Recursos Biologicos Alexander von Humboldt. Bogota, Colombia.

Pirie, T. J., R. L. Thomas, AND M. D. Fellowes. 2016. Limitations to recording larger mammalian predators in savannah using camera traps and spoor. Wildlife Biology 22:13-21.

R Core Team. 2013. R: A language and environment for statistical computing. R Foundation for Statistical Computing, Vienna, Austria. http://www.R-project.org/.

Rocha-Mendes, F., C. L. Neves, R. D. A. Nobre, R. M. Marques, G. V. BiAnConI, AND M. Galetti. 2015. Non-volant mammals from Núcleo Santa Virgínia, Serra do Mar State Park, São Paulo, Brazil. Biota Neotropica 15:e20170358.

Rodríguez, J. P. 2000. Impact of the Venezuelan economic crisis on wild populations of animals and plants. Biological Conservation 96:151-159.

Rodríguez, J. P., AND F. Rojas-Suárez. 2008. Libro Rojo de la Fauna Venezolana. Tercera edición. Provita y Shell de Venezuela, SA. Caracas, Venezuela.

Rovero, F., F. Zimmermann, D. Berzi, and P. Meek. 2013. "Which camera trap type and how many do I need?" A review of camera features and study designs for a range of wildlife research applications. Hystrix, 24:148-156.

Rovero, F., E. Martin, M. Rosa, J. A. Ahumada, and D. Spitale. 2014. Estimating species richness and modelling habitat preferences of tropical forest mammals from camera trap data. PloS One 9:e103300. 
Ruedas, L. A., S. M. Silva, J. H. French, I. I. Platt, R. Nelson, J. Salazar-Bravo, and C. W. Thompson. 2017. A Prolegomenon to the Systematics of South American Cottontail Rabbits (Mammalia, Lagomorpha, Leporidae: Sylvilagus): Designation of a Neotype for S. brasiliensis (Linnaeus, 1758), and Restoration of S. andinus (Thomas, 1897) and S. tapetillus Thomas, 1913. Miscellaneous Publications of the Museum of Zoology, University of Michigan 205:1-67.

Rull, V., E. Montoya, S. Nogué, T. Vegas-Vilarrúbia, and E. Safont. 2013. Ecological palaeoecology in the neotropical Gran Sabana region: long-term records of vegetation dynamics as a basis for ecological hypothesis testing. Perspectives in Plant Ecology, Evolution and Systematics 15:338-359.

Sexton, J. O., X. P. Song, M. Feng, P. Noojipady, A. Anand, C. Huang, D.-H. Kim, K. M. Collins, S. Channan, and C. DiMiceli. 2013. Global, 30-m resolution continuous fields of tree cover: Landsat-based rescaling of MODIS vegetation continuous fields with lidar-based estimates of error. International Journal of Digital Earth 6:427-448.

Sı, X., R. Kays and P. Ding. 2014. How long is enough to detect terrestrial animals? Estimating the minimum trapping effort on camera traps. PeerJ 2:374.

Silveira, L., A. T. de Almeida Jácomo, M. M. Furtado, N. M. Torres, R. Sollmann, And C. Vynne. 2009. Ecology of the giant armadillo (Priodontes maximus) in the grasslands of central Brazil. Edentata Numbers 10:25-35.

Tobler, M. W., S. E. CarrilloPercastegul., R. Leite Pitman., R. Mares, AND G. Powell. 2008. An evaluation of camera traps for inventorying large-and medium-sized terrestrial rainforest mammals. Animal Conservation 11:169-178.

Trolle, M. 2003a. Mammal survey in the southeastern Pantanal, Brazil. Biodiversity and Conservation 12:823-836.

Trolle, M. 2003b. Mammal survey in the Rio Jauaperi region, Rio Negro basin, the amazon, Brazil. Mammalia 67:75-84.

Trolle, M., M. C. Bissaro, and H. M. Prado. 2007. Mammal survey at a ranch of the Brazilian Cerrado. Biodiversity and Conservation 16:1205-1211.

Associated editor: Monica Díaz

Submitted: July 27, 2019; Reviewed: August 19, 2019;

Accepted:September09, 2019; Published on line:February 18, 2020. 
